Check for updates

Cite this: RSC Adv., 2021, 11, 6361

Received 10th December 2020 Accepted 20th January 2021

DOI: 10.1039/d0ra10388h

rsc.li/rsc-advances

\title{
Lithium-ion attack on yttrium oxide in the presence of copper powder during Li plating in a super- concentrated electrolyte $\uparrow$
}

\begin{abstract}
Tohru Shiga, (D) * Yumi Masuoka, Hiroshi Nozaki (D) and Nobuko Ohba (iD
$\mathrm{Li}$ plating/stripping on $\mathrm{Cu}$ and $\mathrm{Y}_{2} \mathrm{O}_{3}\left(\mathrm{Cu}+\mathrm{Y}_{2} \mathrm{O}_{3}\right)$ electrodes was examined in a super-concentrated electrolyte of lithium bis(fluorosulfonyl)amide and methylphenylamino-di(trifluoroethyl) phosphate. In principle, $\mathrm{Li}^{+}$ions cannot intercalate into $\mathrm{a}_{2} \mathrm{O}_{3}$ crystal because its intercalation potential obtained from first-principles calculations is $-1.02 \mathrm{~V}$ vs. $\mathrm{Li}^{+} / \mathrm{Li}$. However, a drastic decrease in the electrode potential and a subsequent constant-potential region were observed during Li plating onto a $\mathrm{Cu}+\mathrm{Y}_{2} \mathrm{O}_{3}$ electrode, suggesting that $\mathrm{Li}^{+}$interacted with $\mathrm{Y}_{2} \mathrm{O}_{3}$. X-ray diffraction (XRD) patterns and $X$-ray absorption fine structure (XAFS) spectra of the $\mathrm{Cu}+\mathrm{Y}_{2} \mathrm{O}_{3}$ electrodes after the Li plating were recorded to verify this phenomenon. The XRD and XAFS results indicated that the crystallinity of $\mathrm{Y}_{2} \mathrm{O}_{3}$ crystals was lowered because of attack by $\mathrm{Li}^{+}$ions or that the $\mathrm{Y}_{2} \mathrm{O}_{3}$ crystal structure was broken while the +3 valence state of $\mathrm{Y}$ was maintained.
\end{abstract}

\section{Introduction}

$\mathrm{Li}^{+}$-ion batteries (LIBs) are one of the most important rechargeable power devices and are essential to hybrid and electric vehicles. Conventional LIBs composed of lithium cobalt oxide $\left(\mathrm{LiCoO}_{2}\right)$ and graphite operate at $3.7 \mathrm{~V}$. One of the challenges in the development of next-generation battery technologies is increasing the cell voltage. The use of lithium transition-metal oxides such as $\mathrm{LiNi}_{0.5} \mathrm{Mn}_{1.5} \mathrm{O}_{4},{ }^{1-3} \mathrm{LiCoPO}_{4},{ }^{4-6}$ or $\mathrm{LiCoMnO}_{4}$ (ref. 7-9) instead of $\mathrm{LiCoO}_{2}$ as a cathode material results in high-voltage cells with an operating voltage of $\sim 5 \mathrm{~V}$. By contrast, for the anode active material, only Li metal can be used to increase the cell voltage. Therefore, research into active materials that can exhibit a redox couple at potentials lower than the Li plating/stripping standard level is a challenge in the development of battery technologies.

Numerous metal oxides have been investigated as anode materials. ${ }^{10}$ For example, niobium(v) oxide $\left(\mathrm{Nb}_{2} \mathrm{O}_{5}\right)$ exhibits oxidation/reduction behavior expressed by the equation $\mathrm{Nb}_{2} \mathrm{O}_{5}$ $+2 \mathrm{Li}^{+}+2 \mathrm{e}^{-} \rightleftharpoons \mathrm{Li}_{2} \mathrm{Nb}_{2} \mathrm{O}_{5}$ at potentials between $2.2 \mathrm{~V}$ and $1.6 \mathrm{~V}$ vs. $\mathrm{Li}^{+} / \mathrm{Li}$. The valence of $\mathrm{Nb}$ changes from +5 to +4 during $\mathrm{Li}^{+}$ intercalation. ${ }^{11,12}$ Thus, for metal oxides to be used as anode materials, they must have more than one valence. However,

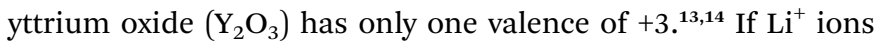
are intercalated into a $\mathrm{Y}_{2} \mathrm{O}_{3}$ crystal, either yttrium ions will be reduced to the metal state or oxygen ions will be oxidized. First-

Toyota Central Research \& Development Laboratories Inc., Yokomichi, Nagakute-city, Aichi-ken, 480-1192, Japan. E-mail: e0560@mosk.tytlabs.co.jp

$\dagger$ Electronic supplementary information (ESI) available. See DOI: 10.1039/d0ra10388h principles calculations show that the intercalation potential of $\mathrm{Li}^{+}$into $\mathrm{Y}_{2} \mathrm{O}_{3}$ is $-1.02 \mathrm{~V}$ (Section 3.2). Therefore, $\mathrm{Y}_{2} \mathrm{O}_{3}$ is theoretically inactive toward $\mathrm{Li}^{+}$insertion; $\mathrm{Li}$ electrodeposition occurs preferentially.

In our previous reports, ${ }^{15,16}$ we examined Li intercalation into graphite in some super-concentrated electrolytes of lithium bis(fluorosulfonyl)amide (LiFSA) and self-extinguishing solvents. Li plating/stripping has also been investigated in this electrolyte using an electrochemical cell with $\mathrm{Cu}$ and $\mathrm{Li}$ metal electrodes. A decrease in the potential of the $\mathrm{Cu}$ electrode because of solid electrolyte interphase (SEI) formation was observed at the initial stage of the Li plating test. After the SEI had formed, a constant-potential region due to Li electrodeposition appeared. In the later stage of Li plating, a sudden decrease of the $\mathrm{Cu}$ electrode potential was observed (Fig. 1). This phenomenon was caused by a large increase in interfacial resistance between the electrolyte and the $\mathrm{Cu}$ electrode. When

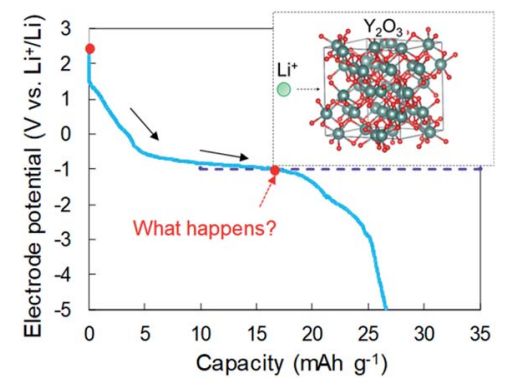

Fig. 1 Schematic of the interaction between a $\mathrm{Li}^{+}$ion and a $\mathrm{Y}_{2} \mathrm{O}_{3}$ crystallite. 
a similar large decrease in potential occurs in a $\mathrm{Cu}+\mathrm{Y}_{2} \mathrm{O}_{3}$ composite electrode, $\mathrm{Li}^{+}$ions are speculated to interact with $\mathrm{Y}_{2} \mathrm{O}_{3}$. The $\mathrm{Li}^{+}$intercalation should be observed at $-1 \mathrm{~V} v s . \mathrm{Li}^{+} / \mathrm{Li}$ if the process occurs as planned (blue dotted line in Fig. 1). In the present paper, we prepared a composite electrode of $\mathrm{Cu}$ and $\mathrm{Y}_{2} \mathrm{O}_{3}$ powders and examined whether $\mathrm{Li}^{+}$ions insert into the $\mathrm{Y}_{2} \mathrm{O}_{3}$ crystallites.

\section{Experimental}

\section{Materials}

$\mathrm{Cu}$ powder was obtained from Kojundo Chemical (average diameter: $1 \mu \mathrm{m})$. $\mathrm{Y}_{2} \mathrm{O}_{3}$ nanopowder was purchased from SigmaAldrich (average diameter: $<100 \mathrm{~nm}$ ). LiFSA as $\mathrm{a} \mathrm{Li}^{+}$salt and methylphenylamino-di(trifluoroethyl) phosphate (PNMePh) as a solvent were obtained from Kishida Chemicals and Tosoh Finechem Corp., respectively. LiFSA was used after drying at $150{ }^{\circ} \mathrm{C}$. The water content in the $\mathrm{PNMePh}$ liquid was $37 \mathrm{ppm}$. Vinylene carbonate (VC), an electrolyte additive, ${ }^{17,18}$ was purchased from Kishida Chemicals (battery grade). The chemical structure of the three compounds was displayed in the ESI (Fig. S1 $\dagger$ ). The X-ray diffraction (XRD) pattern for the $\mathrm{Y}_{2} \mathrm{O}_{3}$ powder is shown in Fig. S2.†

\section{Electrochemical measurements}

The $\mathrm{Cu}+\mathrm{Y}_{2} \mathrm{O}_{3}$ composite electrode was prepared as follows. The $\mathrm{Cu}$ and $\mathrm{Y}_{2} \mathrm{O}_{3}$ powders were mixed with polyvinylidene difluoride (PVdF, \#9350, Kureha) and $N$-methyl pyrrolidone (NMP; Wako Chemicals) using a kneading machine (ARE-310, Thinky Co.). The mixing speed and time were $2200 \mathrm{rpm}$ and $5 \mathrm{~min}$, respectively. The electrode slurry was spread onto a $\mathrm{Cu}$ current collector $(20 \mu \mathrm{m}$ thick) using a doctor-blade technique and dried at $150{ }^{\circ} \mathrm{C}$ under vacuum for $3 \mathrm{~h}$. The final mixing ratio of $\mathrm{Cu}, \mathrm{Y}_{2} \mathrm{O}_{3}$, and $\mathrm{PVdF}$ was $89 \%: 8.5 \%: 2.5 \%$ by weight.

The $\mathrm{Cu}+\mathrm{Y}_{2} \mathrm{O}_{3}$ electrode sheet was pressed to obtain a $14 \mathrm{~mm}$ diameter disk electrode with a thickness of $55 \mu \mathrm{m}$ (Fig. S3†). The loadings of the $\mathrm{Cu}$ and $\mathrm{Y}_{2} \mathrm{O}_{3}$ powders were $28-31 \mathrm{mg} \mathrm{cm} \mathrm{cm}^{-2}$. A half coin cell (Fig. S4 $\dagger$ ) was fabricated using the $14 \mathrm{~mm}$ diameter disk electrode, two filter papers $(200 \mu \mathrm{m}$ thick, ADVANTEC, 5C), a Li metal disk $18 \mathrm{~mm}$ in diameter and $0.4 \mathrm{~mm}$ thick (Honjo Metal), and a super-concentrated electrolyte. The superconcentrated electrolyte was prepared by mixing LiFSA and $\mathrm{PNMePh}$ in a molar ratio of $1: 3$. The cells were fabricated using a dilute electrolyte with the molar ratio of $1: 8$, and $1 \mathrm{~mol} \mathrm{~L}^{-1}$ $\mathrm{LiPF}_{6}$ in a mixture of ethylene carbonate (EC) and dimethyl carbonate (DMC) (Kishida Chemicals, battery grade) in the same manner. The half coin cell was cycled with a chargedischarge apparatus (Hokuto Denko, HJ1001SM8A). The charge (Li plating) was carried out under a current of $0.05 \mathrm{~mA}$. The $\mathrm{Li}$ plating/stripping test was also performed using an electrolyte based on VC at a concentration of $1 \mathrm{vol} \%$. Charging was started under a constant current mode at $0.05 \mathrm{~mA}$ for $24 \mathrm{~h}$, and the discharge (Li stripping) to $2.0 \mathrm{~V}$ was conducted in constantcurrent mode at $0.05 \mathrm{~mA}$.

\section{Cyclic voltammetry (CV)}

The half coin cells were cycled using a potentiometer (IVIUM Technologies, IVIUMSTST-XR) to obtain CV profiles of $\mathrm{Li}$ plating/stripping and $\mathrm{Li}$ intercalation in the highly concentrated electrolyte. A Li-metal anode was used as the counter and reference electrodes. $\mathrm{CV}$ of the electrolytes was conducted under a sweep rate of $0.2 \mathrm{mV} \mathrm{s}^{-1}$ at $25^{\circ} \mathrm{C}$. The $\mathrm{CV}$ curves for the superconcentrated electrolyte are displayed in Fig. S5. $\dagger$

\section{Electrochemical impedance spectroscopy (EIS)}

The $\mathrm{Cu}+\mathrm{Y}_{2} \mathrm{O}_{3}$ electrode in the coin cell was used as a working electrode, and a Li-metal anode was used as the counter and reference electrodes. EIS was conducted at $25{ }^{\circ} \mathrm{C}$ in the frequency range from $7 \mathrm{MHz}$ to $20 \mathrm{mHz}$ with a BioLogic SP-300 potentiostat to investigate the formation of a passive layer on the $\mathrm{Cu}+\mathrm{Y}_{2} \mathrm{O}_{3}$ electrode. It was also conducted between 25 and $51{ }^{\circ} \mathrm{C}$ with the amplitude of the sinusoidal potential adjusted in $10 \mathrm{mV}$ increments. Impedance spectra were fit using the EC-Lab Zfit software.

\section{Analysis}

The $\mathrm{Cu}+\mathrm{Y}_{2} \mathrm{O}_{3}$ electrodes before and after Li plating/stripping were analyzed by XRD (Rigaku, Ultima IV). The $\mathrm{Cu}+\mathrm{Y}_{2} \mathrm{O}_{3}$ electrode sample that contained the electrolyte was affixed to a glassy cell holder using Kapton tape in an Ar-filled glove box. The XRD profile was recorded in the $2 \theta$ range from 10 to $80^{\circ}$ at a sweeping rate of $10^{\circ} \min ^{-1}$. The morphology of Li plating in the sample was examined by field-emission scanning electron microscopy (FESEM, JEOL, JSM-7000F). The $\mathrm{Cu}+\mathrm{Y}_{2} \mathrm{O}_{3}$ electrode was rinsed with DMC three times in an Ar-filled glove box and dried under vacuum. Energy-dispersive X-ray spectroscopy was used to identify passivation films on the $\mathrm{Cu}$, electrodeposited $\mathrm{Li}$, and $\mathrm{Y}_{2} \mathrm{O}_{3} \cdot{ }^{7} \mathrm{Li}$ nuclear magnetic resonance (NMR) spectroscopy was used to examine Li compounds after the Li plating tests; measurements were performed using a Bruker NMR spectrometer (AVANCE 400). In an argon-filled glove box, the $\mathrm{Cu}$ and $\mathrm{Y}_{2} \mathrm{O}_{3}$ powders were stripped from $\mathrm{Cu}$ foil and washed several times with DMC. After drying under vacuum, the powders were packed into a $\mathrm{ZrO}_{2}$ tube. The NMR reference material was $1 \mathrm{~mol} \mathrm{~L}^{-1} \mathrm{LiCl}$ aqueous solution. The measurement conditions are summarized in Table S1. $\dagger$ X-ray absorption fine structure (XAFS) analysis of the $\mathrm{Y}_{2} \mathrm{O}_{3}$ powder after the Li plating test was conducted through-the-law to identify the valence of $\mathrm{Y}$ after the Li plating. In an Ar-filled glove box, the $\mathrm{Cu}$ and $\mathrm{Y}_{2} \mathrm{O}_{3}$ powders were stripped from $\mathrm{Cu}$ foil, washed with DMC several times, and dried under vacuum. XAFS measurements were carried out at the Toray Research Center Inc (Table S2 $\dagger$ ).

\section{Computational details}

First-principles calculations were performed for cubic $\mathrm{Y}_{2} \mathrm{O}_{3}$ crystals using the Vienna $A b$ initio Simulation Package (VASP) ${ }^{\mathbf{1 9}}$ with the generalized gradient approximation of Perdew-BurkeErnzerhof $(\mathrm{PBE})^{\mathbf{2 0}}$ for the exchange-correlation terms in the density functional theory and using the projector-augmented wave (PAW) method ${ }^{21}$ for describing the ion-electron interaction. The cutoff energy for the plane-wave expansion was set to 
$500 \mathrm{eV}$. The spin polarization was considered in all calculations because the total number of electrons may become odd upon $\mathrm{Li}$ insertion. The insertion sites of $\mathrm{Li}$ were estimated using the bond valence sum (BVS), ${ }^{22}$ which is one of the indices used to evaluate the stability of atoms (ions) in a crystal structure. Because the valence of the $\mathrm{Li}^{+}$ion in the oxide was assumed to be +1 , we inserted $\mathrm{Li}^{+}$ions at sites with a BVS close to 1 .

\section{Results and discussion}

\section{Observation of potential drop during $\mathrm{Li}$ plating}

Li plating/stripping was studied in each of the investigated electrolytes. In general, the SEI forms at the initial stage of $\mathrm{Li}$ plating, and it follows the electrodeposition of $\mathrm{Li}$ while a constant voltage is maintained. Electrical shorts due to $\mathrm{Li}$ dendrite growth were detected at the end of Li plating. The first Li plating test in this study was conducted in the superconcentrated electrolyte using an electrode fabricated with only $\mathrm{Cu}$ powder (i.e., without $\mathrm{Y}_{2} \mathrm{O}_{3}$ ). Its potential-capacity curve during the Li plating process is presented in the ESI (Fig. S6 $\dagger$ ). The horizontal axis unit in Fig. S6† is electrical capacity per weight of $\mathrm{Cu}$ powder. The initial stage between A and B reflects SEI formation due to reductive decomposition of the $\mathrm{PNMePh}$ solvent. The region from $\mathrm{B}$ to $\mathrm{C}$ corresponds only to Li plating onto $\mathrm{Cu}$ powder and $\mathrm{Cu}$ foil. A large potential drop was unexpectedly observed when the capacity exceeded $25 \mathrm{~mA} \mathrm{~h} \mathrm{~g}{ }^{-1}$. The potential finally arrived at $-5 \mathrm{~V}$ (point $\mathrm{D}$ ). To determine the cause of the potential drop, we conducted EIS measurements corresponding to points A-D in the potential-capacity curve.

EIS is a powerful method for obtaining information about the electrochemical behavior at electrode-electrolyte interphases. The green line in Fig. 2a represents the Nyquist plot corresponding to point A (pristine) in Fig. S6. $\uparrow$ One distorted semicircle is observed in the high-frequency range from $7 \mathrm{MHz}$ to $667 \mathrm{~Hz}$, and the linear portion of $Z^{\prime}$ and $Z^{\prime \prime}$ appears in the lowfrequency range. An equivalent circuit composed of $R_{\mathrm{e}}$ and two parallel units of resistance and capacity $\left(R_{\mathrm{SEI}}\left|Q_{\mathrm{SEI}}, R_{\mathrm{ct}}\right| Q_{\mathrm{ct}}\right)$ and $Z_{\mathrm{w}}$ in Fig. 2a was used to analyze impedance spectrum A, where $R_{\mathrm{e}}$ is the electrolyte resistance, $R_{\mathrm{SEI}}$ and $Q_{\mathrm{SEI}}$ are the resistance and constant phase element (capacity) ${ }^{\mathbf{2 3 , 2 4}}$ of the SEI on the metallic $\mathrm{Li}$ anode at high frequencies, respectively, $R_{\mathrm{ct}}$ and $Q_{\mathrm{ct}}$ are the charge-transfer resistance at the $\mathrm{Cu}$ electrode-electrolyte interface and the constant phase element for the double-layer
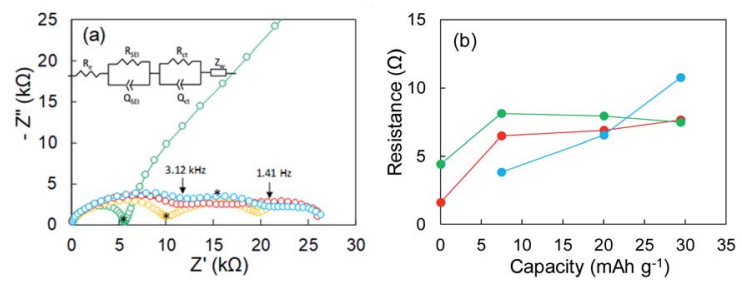

Fig. 2 (a) Nyquist plots of a $\mathrm{Cu}$ powder electrode before Li plating (green) and after $7.5 \mathrm{~mA} \mathrm{~h} \mathrm{~g}^{-1}$ (yellow), $20.1 \mathrm{~mA} \mathrm{~h} \mathrm{~g}^{-1}$ (red), and $29.4 \mathrm{~mA} \mathrm{~h} \mathrm{~g}^{-1}$ (blue) of Li plating. (b) Relation between resistance and Li plating capacity; $R_{\mathrm{SEI}}(\mathrm{red}), R_{\mathrm{ct}}$ (green), and $R_{\mathrm{ct}-\mathrm{c}}$ (blue). The asterisks in subfigure (a) represent portions corresponding to $667 \mathrm{~Hz}$. capacitance at low frequencies, respectively, and $Z_{\mathrm{w}}$ is the Warburg impedance. ${ }^{25,26}$ The analysis results for the pristine sample were $R_{\mathrm{e}}=0.103 \mathrm{k} \Omega, R_{\mathrm{SEI}}=1.596 \mathrm{k} \Omega\left(Q_{\mathrm{SEI}}=5.3 \mathrm{nF}\right)$, and $R_{\mathrm{ct}}=4.421 \mathrm{k} \Omega\left(Q_{\mathrm{ct}}=15.6 \mathrm{nF}\right)$. The Nyquist plot changed dramatically as Li was plated. The Nyquist plots corresponding to points $\mathrm{B}$ and $\mathrm{C}$ are represented by yellow and red lines, respectively, in Fig. 2a. The linear portion of $Z^{\prime}$ and $Z^{\prime \prime}$ for the pristine sample disappeared at frequencies less than $667 \mathrm{~Hz}$, and the second semicircle appeared (yellow line). As Li plating proceeded further, the first semicircle extended horizontally (red line). A third semicircle with a peak at $667 \mathrm{~Hz}$ was detected in the medium-frequency range between $3.12 \mathrm{kHz}$ and $1.41 \mathrm{~Hz}$. The sample in which the potential drop occurred exhibited a larger semi-arc at medium frequencies (blue). For the three samples after Li plating (corresponding to points B, C, and D in Fig. S6 $\dagger$ ), an equivalent circuit comprising three components $\left(R_{\mathrm{SEI}}\left|Q_{\mathrm{SEI}}, R_{\mathrm{cu}-\mathrm{in}}\right| Q_{\mathrm{cu}-\mathrm{in}}, R_{\mathrm{ct}} \mid Q_{\mathrm{ct}}\right)$ was used, where $R_{\text {cu-in }}$ and $Q_{\mathrm{cu}-i n}$ are the charge-transfer resistance and constant phase element in the $\mathrm{Cu}$ powder electrode in the medium-frequency range. ${ }^{27}$ The potential drop was attributed to the SEI on electrodeposited $\mathrm{Li}$ in the $\mathrm{Cu}$ electrode. The resistances for the three components $\left(R_{\mathrm{SEI}}, R_{\mathrm{cu}-\mathrm{in}}\right.$, and $\left.R_{\mathrm{ct}}\right)$ are summarized in Fig. $2 \mathrm{~b}$, and the constant phase elements for each component are shown in Fig. S7. $\uparrow$ The increase in $R_{\text {cu-in }}$ with plating capacity $y$ is characteristic. It was greater than $10 \mathrm{k} \Omega$ at point $\mathrm{D}$. We therefore concluded that a large potential drop was associated with the increase in $R_{\text {cu-in. }}$. The EIS data for the cell fabricated using only $\mathrm{Cu}$ foil as an electrode are shown in the ESI (Fig. S8†). Its EIS performance was similar to that of the $\mathrm{Cu}$ powder electrode.

\section{Calculation of $\mathrm{Li}^{+}$insertion potential}

The $\mathrm{Li}^{+}$insertion potential $(V)$ was estimated from the total energy difference of the reaction $\mathrm{Y}_{2} \mathrm{O}_{3}+1.5 \mathrm{Li}^{+}+\mathrm{e}^{-} \rightarrow \mathrm{Li}_{1.5} \mathrm{Y}_{2} \mathrm{O}_{3}$ by the following equation: ${ }^{28}$

$$
V \approx-\frac{E\left(\mathrm{Li}_{1.5} \mathrm{Y}_{2} \mathrm{O}_{3}\right)-E\left(\mathrm{Y}_{2} \mathrm{O}_{3}\right)-1.5 E(\mathrm{Li})}{1.5 F}
$$

where $F$ is Faraday's constant. The valence for all elements in $\mathrm{Y}_{2} \mathrm{O}_{3}$ and $\mathrm{Li}_{1.5} \mathrm{Y}_{2} \mathrm{O}_{3}$ was estimated by Bader charge analysis ${ }^{29}$ (Table $\mathrm{S} 3 \dagger$ ). The crystal structures of bulk $\mathrm{Y}_{2} \mathrm{O}_{3}$ and $\mathrm{Li}_{1.5} \mathrm{Y}_{2} \mathrm{O}_{3}$ are described in Fig. S9. $\dagger$ The calculated $\mathrm{Li}^{+}$insertion potential was $-1.02 \mathrm{~V} v s . \mathrm{Li}^{+} / \mathrm{Li}$.

\section{Li plating test and XRD analysis}

According to the concept presented in Fig. 1, as Li plating proceeds, the potential of the Cu electrode begins to drop. If $\mathrm{Li}^{+}$ intercalation is assumed to occur, then the potential will soon become constant when it reaches $-1.0 \mathrm{~V}$. To verify this idea, $\mathrm{Li}$ plating tests were conducted with cells fabricated using $\mathrm{Cu}$ powder electrodes with and without $\mathrm{Y}_{2} \mathrm{O}_{3}$ powder. The test results are summarized in Fig. 3a. In the case of the cell without $\mathrm{Y}_{2} \mathrm{O}_{3}$ (green line), the potential of the $\mathrm{Cu}$ electrode showed a constant value of $-0.6 \mathrm{~V}$; it then decreased slowly when the capacity exceeded $20 \mathrm{~mA} \mathrm{~h} \mathrm{~g}^{-1}$, reaching $-5 \mathrm{~V}$ at a capacity of $28 \mathrm{~mA} \mathrm{~h} \mathrm{~g}^{-1}$. By contrast, the cell with a $\mathrm{Cu}+\mathrm{Y}_{2} \mathrm{O}_{3}$ electrode exhibited two potential plateaus; the second plateau was 

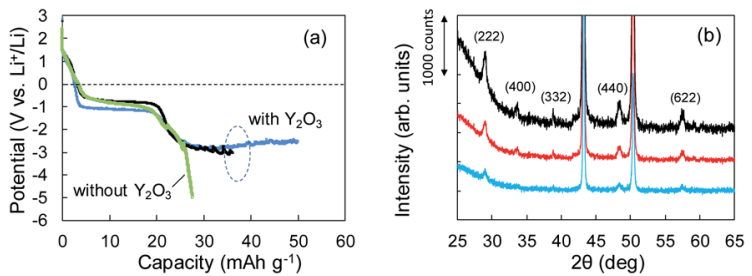

Fig. 3 (a) Potential-capacity curves for Li plating tests without (green) and with (blue, black) $\mathrm{Y}_{2} \mathrm{O}_{3}$. (b) $\mathrm{XRD}$ patterns for $\mathrm{Cu}+\mathrm{Y}_{2} \mathrm{O}_{3}$ electrodes: pristine (black) and after $36.1 \mathrm{~mA} \mathrm{~h} \mathrm{~g}^{-1}$ (red) and $49.8 \mathrm{~mA} \mathrm{~h} \mathrm{~g}^{-1}$ (blue) of Li plating.

observed at $-3 \mathrm{~V} v s . \mathrm{Li}^{+} / \mathrm{Li}$, suggesting an interaction between $\mathrm{Li}^{+}$ions and $\mathrm{Y}_{2} \mathrm{O}_{3}$ crystals. The constant-potential region between 26 and $49.6 \mathrm{~mA} \mathrm{~h} \mathrm{~g}^{-1}$ corresponds to $0.708 \mathrm{~mA} \mathrm{~h}$ of electrical capacity. If $\mathrm{Li}^{+}$insertion follows the reaction $\mathrm{Y}_{2} \mathrm{O}_{3}+$ $1.5 \mathrm{Li} \rightarrow \mathrm{Li}_{1.5} \mathrm{Y}_{2} \mathrm{O}_{3}$, the calculated insertion capacity is 0.541 $\mathrm{mA} \mathrm{h}$ (mass of $\mathrm{Y}_{2} \mathrm{O}_{3}$ in the electrode $=3.04 \mathrm{mg} ; 3.04 \mathrm{mg} \times 0.001$ $\times 26800 \times 1.5 / 225.8=0.541 \mathrm{~mA} \mathrm{~h})$. Thus, the experimental and calculated values are similar. In addition, Li platingstripping (charge-discharge) curves were shown in Fig. S10 and S11. $\dagger$

The $\mathrm{Li}^{+}$insertion may be occurring along with Li plating. To examine the $\mathrm{Li}^{+}$insertion process, we collected XRD patterns of the $\mathrm{Cu}+\mathrm{Y}_{2} \mathrm{O}_{3}$ electrodes after Li plating to $36.1 \mathrm{~mA} \mathrm{~h} \mathrm{~g}{ }^{-1}$ and $49.8 \mathrm{~mA} \mathrm{~h} \mathrm{~g}^{-1}$ (Fig. 3b). The two sharp XRD peaks at $2 \theta=43.34^{\circ}$ and $50.22^{\circ}$ are caused by the $\mathrm{Cu}$ powder and $\mathrm{Cu}$ foil. Five characteristic signals due to $\mathrm{Y}_{2} \mathrm{O}_{3}$ cubic crystals are observed at $2 \theta=29.06^{\circ}, 33.58^{\circ}, 39.68^{\circ}, 48.32^{\circ}$, and $57.58^{\circ}$ in the XRD pattern of the pristine sample. These signals are due to diffractions from the (222), (400), (332), (440), and (622) planes of cubic $\mathrm{Y}_{2} \mathrm{O}_{3}$ crystals, respectively. ${ }^{30,31}$ As the Li plating proceeded, the intensities of these five peaks decreased. These results suggest that the $\mathrm{Y}_{2} \mathrm{O}_{3}$ crystal size decreased or that the crystal structure was destroyed by the insertion of $\mathrm{Li}^{+}$ions. The Li plating tests clearly show that $\mathrm{Li}^{+}$ions attacked and interacted with $\mathrm{Y}_{2} \mathrm{O}_{3}$ crystals at potentials below the standard $\mathrm{Li}$ plating and stripping potentials. To reconfirm this phenomenon, another Li plating/stripping test was conducted in the super-concentrated electrolyte containing $\mathrm{VC}$ as an additive. The test with a discharge current of $0.05 \mathrm{~mA}$ for $24 \mathrm{~h}$ and a charge current of $0.05 \mathrm{~mA}$ to $2.0 \mathrm{~V}$ was repeated for ten cycles. A potential drop similar to that in Fig. 3a was observed in the discharge step of the seventh cycle (Fig. 4a). XRD patterns of the pristine $\mathrm{Cu}+\mathrm{Y}_{2} \mathrm{O}_{3}$ electrodes and those after the fifth cycle and the eleventh cycle are summarized in Fig. $4 \mathrm{~b}$. The five characteristic XRD peaks for $\mathrm{Y}_{2} \mathrm{O}_{3}$ disappeared after the tenth cycle. Fig. $4 \mathrm{~b}$ also shows that the intensity of the XRD signals recovered after $\mathrm{Li}$ stripping. Thus, $\mathrm{Li}^{+}$ions were confirmed to have interacted with $\mathrm{Y}_{2} \mathrm{O}_{3}$ crystals at potentials less than the $\mathrm{Li}$ plating/stripping potentials.

\section{XAFS analysis}

The aforementioned XRD studies indicated that $\mathrm{Li}^{+}$ions might have interacted with $\mathrm{Y}_{2} \mathrm{O}_{3}$ crystals during $\mathrm{Li}$ plating. If $\mathrm{Li}^{+}-$
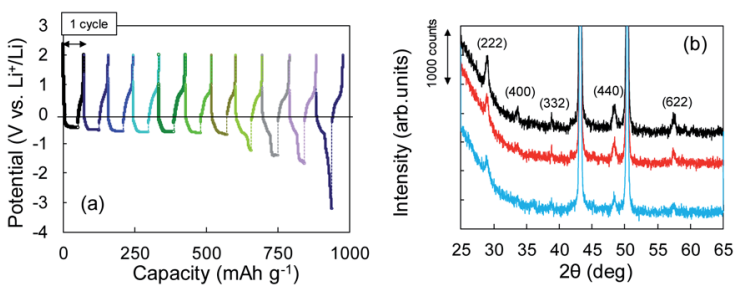

Fig. 4 (a) Potential-capacity curves for Li plating/stripping tests. (b) XRD patterns for $\mathrm{Cu}+\mathrm{Y}_{2} \mathrm{O}_{3}$ electrodes: pristine (black), after the fifth cycle (red), and after the eleventh cycle (blue).

insertion into $\mathrm{Y}_{2} \mathrm{O}_{3}$ occurred, the valence of $\mathrm{Y}$ or the atomic distance between and $\mathrm{Y}$ and $\mathrm{O}$ should have changed. XAFS is a powerful method for characterizing local structures in $\mathrm{Y}_{2} \mathrm{O}_{3}$ crystals. We conducted XAFS measurements for a sample after $55 \mathrm{~mA} \mathrm{~h} \mathrm{~g}^{-1}$ of Li plating. Fig. 5a shows the Y K-end X-ray absorption near edge structure (XANES) spectra of the sample and $\mathrm{Y}_{2} \mathrm{O}_{3}$ crystal powder. The absorption end of $\mathrm{Y}_{2} \mathrm{O}_{3}$ was $17040 \mathrm{eV},{ }^{32}$ and the main absorption peaks were observed in the range from 17050 to $17070 \mathrm{eV}$. In the spectrum of the $\mathrm{Cu}+$ $\mathrm{Y}_{2} \mathrm{O}_{3}$ electrode after the Li plating, the absorption end rise was the same as that observed in the spectrum of the $\mathrm{Y}_{2} \mathrm{O}_{3}$ powder. This result shows that similar XANES profiles were obtained for the $\mathrm{Cu}+\mathrm{Y}_{2} \mathrm{O}_{3}$ electrode after $\mathrm{Li}$ plating and for the $\mathrm{Y}_{2} \mathrm{O}_{3}$ powder even though a slight difference was observed in their main peaks. Therefore, we concluded that the valence of the $\mathrm{Y}$ element in the $\mathrm{Cu}+\mathrm{Y}_{2} \mathrm{O}_{3}$ electrode was +3 .

The extended X-ray absorption fine structure (EXAFS) spectrum is located more than $100 \mathrm{eV}$ from the absorption end, and the Fourier transformation of the real spectrum provides information about the local structure, such as atomic distances. Y K-end FT-EXAFS spectra are displayed in Fig. 5b. The peak of the first close connection, which was associated with $\mathrm{Y}-\mathrm{O}$, appeared in the range from 1.2 to $2.0 \AA$ in the spectrum of the $\mathrm{Y}_{2} \mathrm{O}_{3}$ powder. The peak of the second close connection, which was associated with $\mathrm{Y}-\mathrm{O}-\mathrm{Y}$, was located between 2.7 and $3.4 \AA$. The EXAFS spectral shape of the $\mathrm{Cu}+\mathrm{Y}_{2} \mathrm{O}_{3}$ electrode exhibited the same characteristics as that of the $\mathrm{Y}_{2} \mathrm{O}_{3}$ powder, and the first and second close connections were detected in the same position. Therefore, the coordination environment around $\mathrm{Y}$ in the $\mathrm{Cu}+\mathrm{Y}_{2} \mathrm{O}_{3}$ electrode was similar that around $\mathrm{Y}$ in the $\mathrm{Y}_{2} \mathrm{O}_{3}$ powder. In summary, XANES and EXAFS studies indicated that $\mathrm{Li}^{+}$ions were not inserted into the $\mathrm{Y}_{2} \mathrm{O}_{3}$ crystallites during $\mathrm{Li}$ plating.
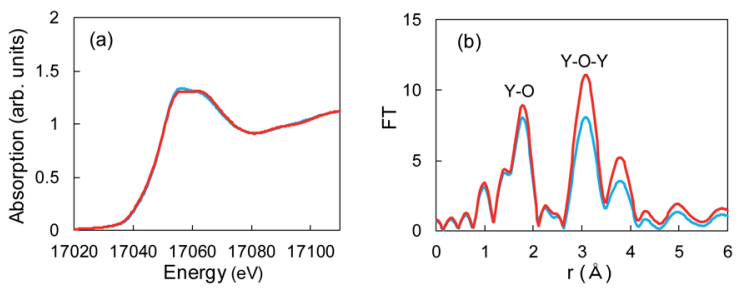

Fig. 5 (a) XANES and (b) EXAFS spectra for $\mathrm{Y}_{2} \mathrm{O}_{3}$ powder (red) and the $\mathrm{Cu}+\mathrm{Y}_{2} \mathrm{O}_{3}$ electrode after the Li plating test (blue). 


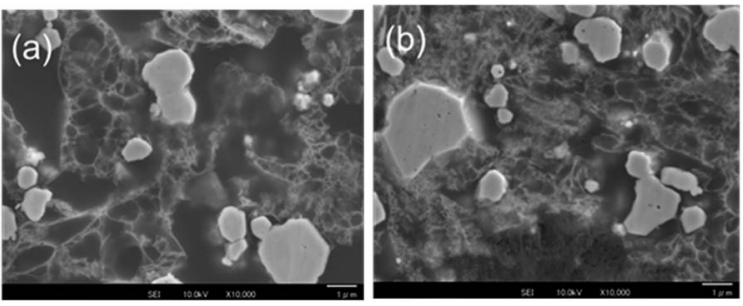

Fig. 6 High-resolution FE-SEM images of the cross section of $\mathrm{Cu}+$ $\mathrm{Y}_{2} \mathrm{O}_{3}$ electrode (a) before and (b) after Li plating. The magnification is $10000 \times$, and the scale bar is $1 \mu \mathrm{m}$.

\section{FE-SEM images and EDX analysis}

The $\mathrm{Li}$ electrodeposition and $\mathrm{Y}_{2} \mathrm{O}_{3}$ powder in the $\mathrm{Cu}+\mathrm{Y}_{2} \mathrm{O}_{3}$ electrode after the $\mathrm{Li}$ plating test to $50 \mathrm{~mA} \mathrm{~h} \mathrm{~g}{ }^{-1}$ was visualized by FE-SEM. Fig. S12a $\uparrow$ shows an FE-SEM image of the cross section of the $\mathrm{Cu}+\mathrm{Y}_{2} \mathrm{O}_{3}$ electrode. The microscope magnification was $1000 \times$. Many needle-like crystals, which may be metallic $\mathrm{Li}$, were observed near the $\mathrm{Cu}$ foil (yellow dotted ellipses). An enlarged FE-SEM image of the needle-like crystal is shown in Fig. S12b. $\uparrow$ FE-SEM images for the $\mathrm{Cu}+\mathrm{Y}_{2} \mathrm{O}_{3}$ electrode at $1000 \times$ magnification are displayed in Fig. $6 \mathrm{a}$ and $\mathrm{b}$ to highlight the $\mathrm{Y}_{2} \mathrm{O}_{3}$. The $\mathrm{Y}_{2} \mathrm{O}_{3}$ powders were aggregated, forming a crosslinking mesh with a large hole before the plating. By contrast, the mesh structure after Li plating was broken, indicating that the $\mathrm{Y}_{2} \mathrm{O}_{3}$ powder exerted some influence during the Li plating.

The SEI films on the $\mathrm{Y}_{2} \mathrm{O}_{3}$ powder, i.e., Li compounds, were further characterized by EDX analysis. We focused on some domains of the $\mathrm{Y}_{2} \mathrm{O}_{3}$ powder with a square of less than $1 \mu \mathrm{m}$ on one side and recorded the elemental distributions for $\mathrm{Y}, \mathrm{O}$, $\mathrm{C}, \mathrm{F}$, and $\mathrm{Cu}$. The EDX measurement positions on the sample after Li plating are displayed in Fig. S13a, $\dagger$ and the EDX results are summarized in Fig. $\mathrm{S} 13 \mathrm{~b}$. $\uparrow$ The EDX results for the sample before Li plating are presented in Fig. S14. $\dagger$ Fig. 7 shows the $\mathrm{Y} / \mathrm{O}$ ratio for the samples before and after $\mathrm{Li}$ plating. The ratio of the sample before the plating varied between 0.8 and 1.8. By contrast, the $\mathrm{Y}_{2} \mathrm{O}_{3}$ domains after the plating were divided into two ranges of $1.6 \leq \mathrm{Y} / \mathrm{O} \leq 1.7$ and $2.1 \leq \mathrm{Y} / \mathrm{O} \leq 3.0$. The latter ratio reflects the domains after the interaction between $\mathrm{Li}^{+}$and $\mathrm{Y}_{2} \mathrm{O}_{3}$. We cannot currently explain why the ratio increases.

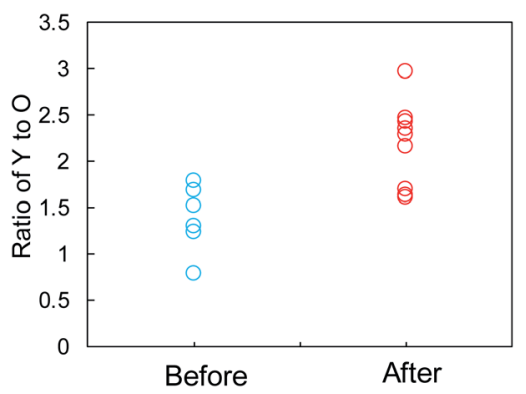

Fig. 7 Comparison of the $\mathrm{Y}$-to-O ratio determined by EDX elemental analysis of the $\mathrm{Cu}+\mathrm{Y}_{2} \mathrm{O}_{3}$ electrode before and after Li plating.
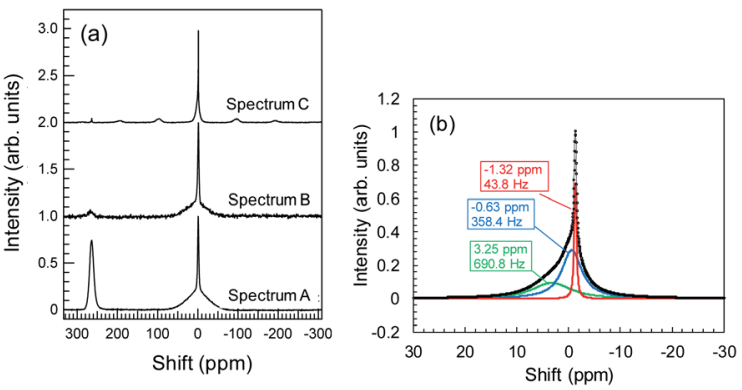

Fig. 8 (a) ${ }^{7} \mathrm{Li}-\mathrm{NMR}$ spectra for $\mathrm{Cu}+\mathrm{Y}_{2} \mathrm{O}_{3}$ electrodes with $\mathrm{Cu}$ foil (spectrum A), without $\mathrm{Cu}$ foil and without rotating (spectrum $\mathrm{B}$ ), and without $\mathrm{Cu}$ foil and with rotating (spectrum C); (b) waveform separation results for spectrum $C$ in the region near 0 ppm.

\section{${ }^{7}$ Li-NMR measurement}

During Li plating tests, many needle-like crystals grew on the $\mathrm{Cu}$ powder and $\mathrm{Cu}$ foil. These crystals may be metallic Li. The metallic Li reacts with the electrolyte, resulting in the formation of SEIs at the surface of the Cu components. In the same manner, $\mathrm{Li}^{+}$ions, which interact with $\mathrm{Y}_{2} \mathrm{O}_{3}$, can induce reductive decomposition of the electrolyte. To characterize the deactivated $\mathrm{Li}$, we conducted ${ }^{7} \mathrm{Li}$-NMR measurements. NMR spectrum A in Fig. 8a corresponds to the sample of $\mathrm{Cu}+\mathrm{Y}_{2} \mathrm{O}_{3}$ electrode involving $\mathrm{Cu}$ foil and LiFSA/PNMePh electrolyte after the Li plating test. A strong peak is observed at $260 \mathrm{ppm}$, which, according to Grey et al., ${ }^{33}$ is attributable to metallic Li. The broad signal at approximately $0 \mathrm{ppm}$ provided information about the $\mathrm{Li}^{+}$ions in LiFSA and Li compounds resulting from the reductive decomposition of electrolyte by metallic $\mathrm{Li}^{34-36} \mathrm{NMR}$ spectra $\mathrm{B}$ and $\mathrm{C}$ correspond to the $\mathrm{Cu}+\mathrm{Y}_{2} \mathrm{O}_{3}$ electrode materials stripped from $\mathrm{Cu}$ foil in measurements conducted without and with rotation of the NMR sample tube. After the $\mathrm{Cu}+\mathrm{Y}_{2} \mathrm{O}_{3}$ electrode was stripped from the $\mathrm{Cu}$ foil, the intensity of the peak due to metallic $\mathrm{Li}$ decreased sharply, indicating that the metallic Li existed in the vicinity of $\mathrm{Cu}$ foil. Because spectrum $\mathrm{C}$ is high-resolution NMR data, we carried out waveform deconvolution for the broad NMR peak at $\sim 0$ ppm. As shown in Fig. 8b, the NMR waveform was deconvoluted into three waves with peaks at $-0.63 \mathrm{ppm}$, $-1.32 \mathrm{ppm}$, or $3.25 \mathrm{ppm}$. The percentage of each peak was $32 \%$, $14 \%$, and $54 \%$, respectively. The wave with the peak at $-1.32 \mathrm{ppm}$ is attributed to $\mathrm{Li}^{+}$ions in the LiFSA/PNMePh electrolyte because it was observed in the spectrum of the pristine sample before the Li plating test (Fig. S15 $\dagger$ ). The other two waves reflected the reductive decomposition. Letellier et al. studied the SEI in $\mathrm{LiPF}_{6} /(\mathrm{EC}+\mathrm{DMC})$ electrolyte using ${ }^{7} \mathrm{Li}-\mathrm{NMR}$ and identified $\mathrm{Li}_{2} \mathrm{CO}_{3}, \mathrm{LiF}, \mathrm{Li}_{2} \mathrm{O}, \mathrm{LiOH}$, and $\mathrm{ROCO}_{2} \mathrm{Li}$ as SEI components. ${ }^{37}$ Because the ${ }^{7} \mathrm{Li}-\mathrm{NMR}$ signal of $\mathrm{LiF}$ appears between 0 and $-1 \mathrm{ppm}$, the wave with the peak of $-0.63 \mathrm{ppm}$ in this study may be due to an analogue of $\mathrm{LiF}$. The ${ }^{7} \mathrm{Li}-\mathrm{NMR}$ signal of $\mathrm{Li}_{2} \mathrm{CO}_{3}$ was detected at $3.89 \mathrm{ppm}$; therefore, the Li compound with a peak at 3.25 ppm is likely an oxide.

\section{Conclusions}

Research into the electrochemical behavior of certain carriers at potentials less than the standard $\mathrm{Li}^{+} / \mathrm{Li}$ plating level is 
a challenging and unknown technical field and will lead to immensely useful anode materials for batteries. $\mathrm{Li}^{+}$insertion into cubic $\mathrm{Y}_{2} \mathrm{O}_{3}$ crystals is theoretically not possible because the insertion potential is $-1.02 \mathrm{~V}$. However, we observed a drastic potential drop of a $\mathrm{Cu}$ electrode during $\mathrm{Li}$ plating onto $\mathrm{Cu}$ in a super-concentrated electrolyte of LiFSA and PNMePh. This unique behavior suggested the possibility of $\mathrm{Li}^{+}$attacking $\mathrm{Y}_{2} \mathrm{O}_{3}$ at a potential of $-1.02 \mathrm{~V}$. In this study, Li plating tests on $\mathrm{Cu}$ were conducted in the presence of $\mathrm{Y}_{2} \mathrm{O}_{3}$ cubic powder. The $\mathrm{Li}$ plating test results and some spectroscopic analyses, including XRD and XAFS, indicate an interaction between $\mathrm{Li}^{+}$and $\mathrm{Y}_{2} \mathrm{O}_{3}$ that leads to a decrease in crystallinity. This unexpected discovery stemmed from our investigation of the decrease in electrode potential in the super-concentrated electrolyte, and we expect similar phenomena to be observed in other highly concentrated electrolyte systems. We speculate that this approach will provide a path for the design of new active materials.

\section{Conflicts of interest}

The authors declare no competing financial interest.

\section{Acknowledgements}

The authors thank Dr Kensuke Takechi of Toyota CRDL for fruitful discussions.

\section{Notes and references}

1 M. Lin, L. Ben, Y. Sun, H. Wang, Z. Yang, L. Gu, X. Yu, X.-Q. Yang, M. Armand and X. Huang, Chem. Mater., 2015, 27, 292-303.

2 W.-K. Shin, Y.-S. Lee and D.-W. Kim, J. Mater. Chem. A, 2014, 2, 6863-6869.

3 X. Zhang, F. Cheng, J. Yang and J. Chen, Nano Lett., 2013, 6, 2822-2825.

4 N. N. Bramnik, K. Nikolowski, C. Baehtz, K. G. Bramnik and H. Ehrenberg, Chem. Mater., 2007, 19, 908-9215.

5 K. J. Kreder III, G. Assat and A. Manthiram, Chem. Mater., 2015, 7, 5543-5549.

6 J. G. Lapping, O. J. Borkiewicz, K. M. Wiaderek, J. L. Allen, T. R. Jow and J. Cabana, ACS Appl. Mater. Interfaces, 2020, 12, 20570-20578.

7 D. Pasero, S. de Souza, N. Reeves and A. R. West, J. Mater. Chem., 2005, 15, 4435-4440.

8 M. Hu, Y. Tian, L. Su, J. Wei and Z. Zhou, ACS Appl. Mater. Interfaces, 2013, 5, 12185-12189.

9 L. Che, X. Fan, E. Hu, D. Su, X. Yang and C. Wang, Chem, 2019, 5, 1-17.

10 M. V. Reddy, S. Rao and B. V. R. Chowdari, Chem. Rev., 2013, 113, 5364-5457.

11 V. Augustyn, J. Come, M. A. Lowe, J. W. Kim, P.-L. Taberna, S. H. Tolbert, H. D. Abruna, P. Simon and B. Dunn, Nat. Mater., 2013, 12, 518-522.
12 K. J. Griffith, A. C. Forse, J. M. Griffin and C. P. Grey, J. Am. Chem. Soc., 2016, 138, 8888-8899.

13 M. B. Korzenski, P. Lecoeur, B. Mercey, D. Chippaux and B. Raveau, Chem. Mater., 2000, 12, 3139-3150.

14 A. B. Rahane, P. A. Murkute, M. D. Deshpande and V. Kumar, J. Phys. Chem. A, 2013, 117, 542-5550.

15 T. Shiga, Y. Kato, H. Kondo and C. Okuda, J. Mater. Chem. A, 2017, 5, 5156-5162.

16 T. Shiga, C. Okuda, Y. Kato and H. Kondo, J. Phys. Chem. C, 2018, 122, 9738-9745.

17 L. E. I. Ouatani, R. Dedryvere, C. Slret, P. Blensan, S. Reynaud, P. Iratqabal and D. Gonbeau, J. Electrochem. Soc., 2009, 156, A103-A113.

18 L. Madec, R. Petibon, J. Xia, J.-P. Sun, I. G. Hill and J. R. Dahn, J. Electrochem. Soc., 2015, 162, A2635-A2645.

19 G. Kresse and J. Furthmuller, Phys. Rev. B: Condens. Matter Mater. Phys., 1996, 54, 11169-11186.

20 P. E. Blochl, Phys. Rev. B: Condens. Matter Mater. Phys., 1994, 50, 17953-17979.

21 J. P. Perdew, Phys. Rev. Lett., 1985, 55, 1665-1668.

22 I. D. Brown, Chem. Rev., 2009, 109, 6858-6919.

23 M. B. Singh and R. J. Kant, J. Phys. Chem. C, 2014, 118, 51225133.

24 P. Corodoba-Torres, T. J. Mesquita and R. P. Nogueira, J. Phys. Chem. C, 2015, 119, 4136-4147.

25 A. R. C. Bredar, A. L. Chown, A. R. Burton and B. H. Farnum, ACS Appl. Energy Mater., 2020, 3, 66-98.

26 J. E. Morales-Ugarte, E. Bolimowska, H. Rouault, J. SantosPena, C. C. Santini and A. Benayard, J. Phys. Chem. C, 2018, 122, 18223-18230.

27 W. Zhang, F. H. Richter, S. P. Culver, T. Leichtweiss, J. G. Lozano, C. Dietrich, P. G. Bruce, W. G. Zeier and J. Janek, ACS Appl. Mater. Interfaces, 2018, 10, 22226-22236. 28 Y. S. Meng and M. E. Arroyo-de Dompablo, Energy Environ. Sci., 2009, 2, 589-609.

29 M. Yu and D. R. Trinkle, J. Chem. Phys., 2011, 134, 064111.

30 M. B. Korzenski, P. Lecoeur, B. Mercey, D. Chippaux and B. Raveau, Chem. Mater., 2000, 12, 3139-3150.

31 P. Rouffignac, J.-S. Park and R. G. Gordon, Chem. Mater., 2005, 17, 4808-4814.

32 P. Lindqvist-Reis, K. Lamble, S. Pattanaik, I. Persson and M. Sandstrom, J. Phys. Chem. B, 2000, 104, 402-408.

33 R. Bhattacharyya, B. Key, H. Chen, A. S. Best, A. F. Hollenkamp and C. P. Grey, Nat. Mater., 2010, 9, 504510.

34 A. I. Freytag, A. D. Pauric, S. A. Krachkovskiy and G. R. Goward, J. Am. Chem. Soc., 2019, 141, 13758-13761.

35 M. Tang, V. Sarou-Kanian, P. Melin, J.-B. Leriche, M. Menetrier, J.-M. Tarascon, M. Deschamps and E. Salager, Nat. Commun., 2016, 13284.

36 L. A. Huff, H. Tavassol, J. L. Esbenshade, W. Xing, Y.-M. Chiang and A. A. Gewirth, ACS Appl. Mater. Interfaces, 2016, 8, 371-380.

37 M. Letellier, F. Chevallier and M. Morcrette, Carbon, 2007, 45, 1025-1034. 